This is the version of the article accepted for publication in Inter-Asia Cultural Studies17 (3), 357-374 published by Taylor \& Francis available at: $\underline{\text { http://dx.doi.org/10.1080/14649373.2016.1217630 }}$

Accepted version made available via SOAS Research Online: http://eprints.soas.ac.uk/23080/

\title{
Ganga Bahadur's books: landmark proletarian novels and the Nepali communist movement
}

Michael Hutt, SOAS University of London

\begin{abstract}
Based on literary research and interviews conducted in Kathmandu, this article takes as its starting point the contents of a bookcase belonging to an ex-Maoist combatant now living in retirement in Kathmandu and the "syllabus" promulgated by the then Communist Party of Nepal (Maoist) for the ideological training of its cadres. It goes on to chronicle the process by which a number of "landmark 'proletarian novels"” (Denning 2007, 706) came to be translated into Nepali from Russian and Chinese, and the ways in which Maoist cadres were inspired and influenced by these works during the course of the "People's War" in Nepal between 1996 and 2006. Finally, the discussion moves to a consideration of the relationship between the impact of these translated texts in the Nepali context and broader conceptualisations of "world literature."
\end{abstract}

Keywords: Nepal, Soviet Union, China, Maoism, communism, translation, world literature

\section{Introduction}

This is a discussion of the afterlife of a number of "landmark "proletarian novels"" (Denning 2007, 706) which travelled abroad in translated forms to inspire communists and revolutionaries in other countries, decades after their original publication. One such country was Nepal, where a communist movement has existed in opposition to a politically active monarchy and centrist political parties since the late 1940s.

It is reasonably easy to trace the historical currents that shaped and sustained the Nepali communist movement from its origins in India during the 1940s up to the tenyear Maoist war against the Nepali state that ended in 2006. However, little work has yet been done on the ways in which literature, and particularly literature translated from Chinese and Russian, played an important role as a bearer of communist 
This is the version of the article accepted for publication in Inter-Asia Cultural Studies17 (3), 357-374 published by Taylor \& Francis available at: $\underline{\text { http://dx.doi.org/10.1080/14649373.2016.1217630 }}$

Accepted version made available via SOAS Research Online: http://eprints.soas.ac.uk/23080/

ideology to Nepal, or on how this literature influenced literary production in the languages of Nepal.

This article is an attempt to explain how it was that a small number of Russian and Chinese works of fiction contributed to the formation of a revolutionary subjectivity in Nepal, particularly among the Nepali Maoist rebels of the late $20^{\text {th }}$ century. In my conclusion, I will ask how the translation of these novels into a minor regional language and their impactful circulation in a context very different from those in which they were first produced, but beyond the gaze of the "international literary authorities" (Casanova 2004, 183), and ignored by most Nepali literary historians, ${ }^{1}$ relates to ongoing debates on the conceptualisation of "world literature."

\section{Ganga Bahadur Lama's books}

The subject of this article first suggested itself to me in 2012, when I met a man named Ganga Bahadur Lama, whose account of his experiences as a Maoist revolutionary (Lama 2008-9) I had read two years earlier in the course of my research on Nepali Maoist memoirs (see Hutt 2013). ${ }^{2}$ Born in 1961 into a family of Tamangs, Nepal's most marginalised and disadvantaged hill minority, Ganga Bahadur Lama was first drawn into Left politics in the aftermath of a student rebellion in Kathmandu in 1979, and joined the Nepal Communist Party (Unity Centre) in 1990. He took part in Kathmandu Valley-based Maoist actions at the beginning of the People's War, later organized Maoist activities among the local Tamang population of the hill district of Dhading, and then led a propaganda campaign across the villages of the Gandaki district. In 2003 he was seriously injured in a Royal Nepalese Army assault, as a result of which he had to have a leg amputated in 2004 (Adhikari 2014, 145-50; Hutt 2013, 126). After the Comprehensive Peace Agreement of 2006, Ganga Bahadur received financial compensation from the Nepali government and when I met him he lived in rented accommodation near the northern edge of the Kathmandu urban area.

To be truthful, it was actually my encounter with Ganga Bahadur Lama's collection of books, rather than with Ganga Bahadur Lama himself, that really piqued my interest. A bookcase in his small apartment was packed with Nepali translations of works of political and revolutionary theory by Marx, Engels, Lenin and Mao, all of which he claimed to have read. Although I am reluctant to cast doubt on the veracity 
This is the version of the article accepted for publication in Inter-Asia Cultural Studies17 (3), 357-374 published by Taylor \& Francis available at: $\underline{\text { http://dx.doi.org/10.1080/14649373.2016.1217630 }}$

Accepted version made available via SOAS Research Online: http://eprints.soas.ac.uk/23080/

of his claim, it would be remarkable if it were true, as these texts are both conceptually and linguistically challenging for a Nepali reader whose education has not passed the SLC level, and several of them were hefty, to say the least. The claim, none the less, is significant, and points to the fact that the Maoist movement in Nepal was often "self-consciously pedagogical" (Zharkevich 2013,108), and attempted to instil a sense of the importance of study in its cadreship.

Ganga Bahadur Lama told me that the habit of reading and studying was strong among the first wave of Maoist recruits, of which he was one. He said they were more ideologically driven than the latecomers who joined after the second round of peace talks in 2003, who, in his words, “didn't come in order to transform the world." $\mathrm{He}$ had purchased and read some of the canonical Marxist novels when he was younger, and cited a number of Russian and Chinese titles that cropped up regularly in subsequent conversations (and are discussed below), plus a book he called "Mister Glad," which he had found especially inspiring. He said that these books were "necessary to arouse our hunger in the beginning" and to produce energy (urja) in people as they went into the "People's War.",

\section{The Maoist schooling syllabus}

Although I believe that such novels had a much greater impact upon Ganga Bahadur Lama and his comrades than the other tomes displayed in his bookcase, it is important to note that the Nepali Maoist leadership did make a concerted effort to familiarise its cadres with works of political theory. Almost all of the dozen or so erstwhile Maoist combatants I have interviewed since 2010, and many of those whose published memoirs I have read, attended what they invariably call a "schooling programme," which was designed to acquaint Maoist cadres with the fundamental tenets of communist thought. This programme is said to have run for the duration of the "People's War" of 1996-2006, and to have been based on an approved syllabus of readings. ${ }^{4}$

The precise content of the original syllabus is not easy to ascertain. In 2012 I acquired a photocopy of a 44-page syllabus first published by the Jan Mukti Sena (People's Liberation Army, or "PLA")'s western command in 2004. ${ }^{5}$ The introduction to this is provided by Comrade Prabhakar, who in 2007 was the PLA Deputy 
This is the version of the article accepted for publication in Inter-Asia Cultural Studies17 (3), 357-374 published by Taylor \& Francis available at: $\underline{\text { http://dx.doi.org/10.1080/14649373.2016.1217630 }}$

Accepted version made available via SOAS Research Online: http://eprints.soas.ac.uk/23080/

Commander. Quoting liberally from Lenin, Mao and the Nepali Maoist leader

"Prachanda," Prabhakar stresses the need for all Nepali revolutionaries to study historical materialism, writing, "Without a grasp of the true meaning of revolutionary theory it is mere foolishness even to imagine using it." Prabhakar argues that the revolution is a university in its own right and reasserts the need for revolutionary learning, even in the changed political context that follows the ending of armed conflict. He explains that the syllabus has been reprinted in a revised form to ensure that intellectual work is made even more effective during this peaceful phase of the revolution.

The syllabus contains references to 394 works and is divided into four sections: Philosophy; Political Economy; Scientific Socialism; Military Science. The vast majority of the texts are in Nepali, with a small number in Hindi or English. Most are authored by Mao, Lenin, Marx and Engels, though there is a sprinkling of works by the Nepali Maoist leader "Prachanda" (Pushpa Kamal Dahal), six works by Stalin and one each by the Nepali Maoist ideologues "Kiran” (Mohan Baidya) and Baburam Bhattarai.

In the early years of the "schooling," curricular materials were in short supply. A former cadre from Dandeldhura told me that some of the senior leadership possessed copies of Hindi translations of the communist manifesto and other standard texts, but otherwise for the rank and file there was a severe shortage of books. Additionally, books linked with Mao's name were "pretty much banned" in Nepal. So in 2001-2 this cadre was sent to Chandigarh in Panjab several times to collect consignments of books for Maoist units in western Nepal. Before the conflict intensified with the government's declaration of an Emergency in November 2001 it was not difficult to smuggle them into Nepal, but afterwards it became necessary to bring them over the border by boat, up the Mahakali river. ${ }^{6}$

Ex-combatants' assessments of the usefulness of this schooling varied. Ganga Bahadur Lama described it as "of a rather one-sided nature, dedicated to the leadership" and with an emphasis on the "power-comes-from-the-barrel-of-a-gun type of literature." The insurgents weren't given much to read about how to transform society, but more about Mao's military science (sainya vigyan): “things that would excite people, make them throw themselves into battle, be loyal (bafadar) to the leadership." In his opinion, the Maoists didn't emphasise reading so much as a way of 
This is the version of the article accepted for publication in Inter-Asia Cultural Studies17 (3), 357-374 published by Taylor \& Francis available at: $\underline{\text { http://dx.doi.org/10.1080/14649373.2016.1217630 }}$

Accepted version made available via SOAS Research Online: http://eprints.soas.ac.uk/23080/

making what he called "the second man" emerge; it was more for the purposes of warfare. Although some activists did study political philosophy there was little scope for them to implement what they learned in practice: "understanding was one thing, the work you had to do was another."7

But Informant A, a younger woman who had served as a Maoist district commander, saw more value in it, and thought that it provided an ideological foundation that made it easier for ordinary cadres to persuade ordinary villagers of the justice of their cause. She told me,

You went among the people and gave a lecture. You explained why you had joined the People's War and what your objective was, you explained the oppression (utpidan) that was current in society: that is a kind of schooling. You explained to the people why they had to give you food, lodgings, to convince them: that is schooling too. That was called people's education. So it went to the public level. $^{8}$

Several others impressed upon me the fact that although texts such as the collected works of Mao were difficult for them to understand they persevered in their efforts to do so:

We had to read it, so we read. So much we understood and so much we didn't understand! There was no telling off (gali) if you didn't read it, but we had to go among the people and give them classes, and if we didn't understand it how could we teach them? So we read with great effort (ekdam mehnatka sath) and we asked the elder brothers (daiharu) about the parts we didn't understand. ${ }^{9}$

However, the fact remains that many Maoist cadres found the literature of the prescribed syllabus very dry and difficult to understand. As Informant A told me, "People used to say: 'If you're going to a philosophy class take a thermos of tea!' Many teachers managed to explain it very clearly, but others used all the big wordschetna (consciousness), padartha (material)—and it was incomprehensible." Another former cadre told me that many of the "Wholetimers" were not particularly interested. 
This is the version of the article accepted for publication in Inter-Asia Cultural Studies17 (3), 357-374 published by Taylor \& Francis available at: $\underline{\text { http://dx.doi.org/10.1080/14649373.2016.1217630 }}$

Accepted version made available via SOAS Research Online: http://eprints.soas.ac.uk/23080/

He said they hadn't learned much about class and so on at school, where they had received a "bourgeois education." 10

Even Hemanta Oli, the senior Maoist official who compiled the syllabus, admitted that its content presented serious challenges for many cadres, and explained that it was therefore necessary for instructors to simplify it, put it into village language, and even attempt to apply it to an agricultural context. ${ }^{11}$ Informant A recalled that the Maoist leader Mohan Baidya ("Kiran") produced a booklet in clear simple language about the various "isms" ( $\mathrm{vad}$ ) that cadres needed to understand:

The reason I remember this booklet so well is that a bhai [younger brother] from Amchora village came out as a Wholetimer. When he came out that booklet had just recently arrived. And I had received some for distribution in my area so I gave him one. And he read it all night, lighting a lamp to read it by. And in the morning his father came to take him back home. He was very young, you see. His father was a headmaster. And he said "Father, do you know what materialism (bhautikvaad) is?" His father had never heard of it. And he gave him a complete definition of it. He was about 15 or 16. And his father said, "In one night you learned all that?" And he said, "If I can learn that in a night, how much more I will learn in a few months!"12

But several cadres felt able to admit that much of what they were required to read went right over their heads. Laughing, one woman told me: “Oh don't ask about those books! They were part of the training, they were taught to us." She mentioned a book by Engels and said, 'I still don't understand that one. I've no idea what it was all about (kata ke ho ke ho..!)"13

\section{The impact of the proletarian novel}

Despite the claims of some cadres that they profited from their readings of the prescribed works on the schooling syllabus, it was widely admitted that it was another kind of text - the novels mentioned by Ganga Bahadur Lama during our first discussion of his book collection - that had the more immediate and profound effect upon them. One female cadre told me, 
This is the version of the article accepted for publication in Inter-Asia Cultural Studies17 (3), 357-374 published by Taylor \& Francis available at: $\underline{\text { http://dx.doi.org/10.1080/14649373.2016.1217630 }}$

Accepted version made available via SOAS Research Online: http://eprints.soas.ac.uk/23080/

The theoretical material was hard to understand, we would read it once and not understand, but we had to understand it or we wouldn't be able to do anything. Once we had got into the habit of reading novels and stories, it became easier to get inside the other stuff, and it was enjoyable too. ${ }^{14}$

Another said,

Sometimes we would feel fed up (bor lagthyo) during PLA activities, and if we had not read such books as these, we would not have had that energy (urja) inside us. Sometimes when our state of mind was becoming distorted (bikrit), those books would control us. Sometimes there was sorrow (dukha), there was suffering (kashta), sometimes I wondered why I had left my home and family, why I had left the town, I had given up school studies and come like this, I felt like just going home, sometimes I felt like this when there was $d u k h a$ and kashta, then when I heard these songs and music, and read these stories and novels, I thought "No, it would be wrong for me to do this," so they played a very important role. ${ }^{15}$

The texts in question were produced during, or inspired by, socialist revolutions in the "communist second world" during the early to mid- $20^{\text {th }}$ century. During these years "the official conventions of socialist realism were ritualized into a form of didactic popular literature" (Denning 2007, 703), producing what Denning calls "landmark 'proletarian novels"” (Denning 2007, 706). Even Hemanta Oli, the compiler of the "schooling syllabus," was able to recite a list of them. I asked a group of six female ex-cadres what the key books were for them and their contemporaries and after a brief discussion they came up with the same list of Nepali titles as Ganga Bahadur Lama had recited to me some days earlier: Chamkilo Rato Tara [Bright Red Star], Aama [Mother], Yuvaharuko Git [The Song of the Youths], Agnidiksha [Fire Initiation], and one English title: Thank You Mr Glad. ${ }^{16}$ Before looking at these five works a little more closely and attempting to understand their appeal to young Nepali revolutionaries in the last years of the twentieth century, I will explore the context in which they came to be translated into Nepali. 
This is the version of the article accepted for publication in Inter-Asia Cultural Studies17 (3), 357-374 published by Taylor \& Francis available at: $\underline{\text { http://dx.doi.org/10.1080/14649373.2016.1217630 }}$

Accepted version made available via SOAS Research Online: http://eprints.soas.ac.uk/23080/

\section{The Chinese and Russian presence in Panchayat-period Nepal}

On 13 July 2012, with the help of the shopkeeper's assistant, I established that Pragati Pustak Bhandar (Figure 1), one of Kathmandu's better known communist bookshops, established in 1991, stocked a total of 62 Russian and Chinese titles in Nepali translation, including multiple copies of the novels cited above. Very little has been written on the topic of how this literature came to be translated. The following account therefore relies heavily upon the memories of some of the protagonists in this process.

(Notes to typesetter: Please insert "HUTT_Figure01.JPG" here. Thank you.)

Figure 1. The interior of Pragati Pustak Bhandar (Progress Book Store) in Bag Bazaar, Kathmandu.

In the years leading up to the end of the autocratic Rana regime in 1951, Nepal's educated minority came increasingly into contact with political ideologies emanating from beyond the Indian subcontinent. Much if not all of this ideology reached them via India, of course, and included ideas of political non-alignment, development, communism, and democracy in various shapes and forms:

Nepal was a small country, we had never been a colony but we were never independent either. We are very influenced by the experiences of neighbouring countries: economic dependency, intellectual dependency. ${ }^{17}$

In his history of the communist movement in Nepal, Surendra KC gives a sketchy account of early efforts by local activists to import and distribute communist literature in Nepal during the 1930s (KC 1999, 37-40). These efforts were local and sporadic, partly because the potential readership was tiny, and partly because such efforts were extremely dangerous under Rana rule. The first major influx of such material occurred during the Cold War, when India, the USA, China and the Soviet Union began to compete for influence over the direction of Nepal's political and economic development. Each of these countries provided development aid in various 
This is the version of the article accepted for publication in Inter-Asia Cultural Studies17 (3), 357-374 published by Taylor \& Francis available at: $\underline{\text { http://dx.doi.org/10.1080/14649373.2016.1217630 }}$

Accepted version made available via SOAS Research Online: http://eprints.soas.ac.uk/23080/

shapes and forms, but alongside this, as one senior literary scholar put it, "Russia and China used literature as a means to spread communism to places where they could not use weapons."

They did so in very different ways, however. The Chinese began by making printed propaganda and translations of revolutionary fiction available either very cheaply or for free in Nepal. Often, their publications contained colour photos, were printed on glazed paper and were bound in hard covers, in sharp contrast to the much lower-quality output of Nepali publishers. The works of several popular Chinese writers could be bought very cheaply: for instance, Khagendra Sangraula recalls buying all four volumes of Lu Hsun's writings for 12 rupees in the 1970s. It was rumoured that Nepali distributors received copies of such books from China for free, then sold them cheaply. For instance, while he was a student in Dharan in 1966-7, Basanta Thapa of the Himal Association ran a pavement stall in the mornings and afternoons, selling publications such as China Pictorial, Chin Sachitra (in Hindi), and Peking Review, which were sent to him from Kathmandu by the Maoist bookshop and publisher Pragati Prakashan (see below). ${ }^{19}$

The Chinese initiatives did not go unopposed. Dhruba Kumar describes the distribution of Chinese revolutionary literature and Mao badges and screening of revolutionary films for Chinese construction labourers and local peasants in the eastern hills during and after the Chinese road building projects that began there in 1963, and a reaction which took place against perceived Chinese incursions on Nepal's sovereignty from pro-Panchayat and pro-monarchy elements in July 1967. The demonstrators "hurled stones at the Nepal-China Friendship Association on New Road and simultaneously raided a book store at Bhotahity that sold communist literature" (Kumar 1980, 29; see also Adhikari 2014, 1-3).

The inflow of Russian literature into Nepal began largely as a side product of the more substantial literary and ideological engagement that developed between the USSR and India from the 1920s onward. A book entitled Samyavad (Communism) by Shivanarayan Mishra Vaidya was published in 1919 from the office of the popular Hindi daily Pratap (Tripathi 1978, 4), and writings on Lenin and communism began to appear in Bengali from the early twenties (Chattopadhyay 1978, 21; Sanyal 1978, 33). The Bengali poet Nazrul Islam "made the first Bengali rendering" of the Internationale in 1927 (Choudhary 1978, 24) and a Bengali translation of the 
This is the version of the article accepted for publication in Inter-Asia Cultural Studies17 (3), 357-374 published by Taylor \& Francis available at: $\underline{\text { http://dx.doi.org/10.1080/14649373.2016.1217630 }}$

Accepted version made available via SOAS Research Online: http://eprints.soas.ac.uk/23080/

Communist manifesto was serialised in Ganavani, the mouthpiece of the Peasants and Workers Party, in 1927-8 (26). Three different Bengali translations of Gorki's "Mother" were serialised in Samhati, Ganavani and Atmasakti (26) and the first Telugu translation appeared in 1934 (Anjaneyulu 1978, 67).

The Soviet materials produced in Indian languages during the 1950s were comprehensible and available to most members of the Nepali political classes. It would seem that the Soviet authorities were not especially bothered about reaching a wider Nepali readership until somewhat later, ${ }^{20}$ possibly to counter Chinese influence in Nepal. The substantial growth of the literate population of Nepal during the 1970s and 1980s led to the emergence of a small but growing market for translations in Nepali, which represented an opportunity for pro-Moscow and pro-Beijing ideologues alike.

A memoir published by Arbinda $\operatorname{Rimal}^{21}$ in 2005 sheds some interesting light on the development of Soviet activities in Nepal, seen from a Nepali perspective. Rimal (b.1934) was attracted to communism while he was studying in Calcutta in the late 1940s. When he returned to Kathmandu in April 1951, he and several of his peers organised a "Progressive Study Circle" (pragatishil adhyayan mandal):

We began to study Marxist-Leninist literature and philosophy night and day. We believed that in order to concretise, protect and reinforce every progressive change in the world we needed also to be active, dedicated and committed to introducing such changes in our own country, and this broadened our perspective. The aspirations and objectives of the people of Soviet Russia, China, Vietnam, India, Malaya, Burma, Indonesia, the Philippines, Greece and Turkey, and wherever else, became our common aspirations and objectives too. (Rimal 2005, 145)

These young men read an interesting mixture of texts (eg., Lenin's What is to be Done? and The State and Revolution, Julius Fucik's Notes from the Gallows, Nehru's The Discovery of India, Edgar Snow's Red Star over China) and adopted the "great Soviet Union" as the "ideal and symbol of our political action, propagation and struggle." At a time when the Soviet Union was being "slandered" by western governments, they considered it their "patriotic internationalist duty" to tell the Nepali 
This is the version of the article accepted for publication in Inter-Asia Cultural Studies17 (3), 357-374 published by Taylor \& Francis available at: http://dx.doi.org/10.1080/14649373.2016.1217630

Accepted version made available via SOAS Research Online: $\underline{\text { http://eprints.soas.ac.uk/23080/ }}$

people the truth about Soviet power and the Soviet people. They were also inspired by the Chinese revolution and the struggles of the "common people" in India and elsewhere (Rimal 2005, 146), but, like the latterday Nepali Maoists, they were nationalists as much as they were communists, and Rimal became suspicious of China's intentions when he read Mao's claim in The Chinese Revolution and the Chinese Communist Party that Nepal belonged historically to China.

In 1959 Rimal left his young family in Kathmandu and travelled to Delhi, where he had been offered a job as a Nepali translator for Soviet Bhumi, a fortnightly bulletin published by the Soviet Information Department in over a dozen different South Asian languages: the Nepali edition had begun in August 1958 (Rimal 2005, 440). The circulation of the Nepali edition increased, both in Nepal and in the Nepalispeaking regions of India. It regularly carried local content, including articles about Nepal by Soviet authors and original pieces by established Nepali writers (see Chauhan 2005) and letters to the editor from the readership. In 1968 Rimal moved to Kathmandu with most of the other Nepali staff, and became the editor of a daily bulletin entitled "News and Views from the USSR" (Sobhiyat Sanghaka Samachar ra Bichar). This publication, which usually ran to around a dozen pages, contained analyses of and commentaries on world events from a Soviet perspective.

During the latter half of the Panchayat period, approximately 2000 Nepalis were granted scholarships to study in the Soviet Union (a list of alumni may be found in Mitra Kunj [2000]) and several of them stayed on or returned to work for the Soviet broadcasting stations or as translators for Soviet publishers, notably Progress Publishers, established in Moscow in 1931. Progress published a wide range of books, including not only the works of Marx, Engels and Lenin but also political primers, fiction, and children's literature. It took over the role of the Foreign Languages Publishing House in 1963 and a group of Moscow-based Nepali students are said to have established a "World Literature Translation Institute" in 1969 (Shrestha 2000, 131), but Progress Publishers did not begin a coordinated programme for the translation of Russian texts into Nepali until some time after this. Krishna Prakash Shrestha was their first Nepali translator, joined by Rajendra Maske and Suryaprakash Paudyal later on. Raduga ("Rainbow") Publisher was established in 1982, and this took over the publication of translations of literary classics from Progress. ${ }^{22}$ In South Asia, it was not only avowed communists who read books published by Progress 
This is the version of the article accepted for publication in Inter-Asia Cultural Studies17 (3), 357-374 published by Taylor \& Francis available at: $\underline{\text { http://dx.doi.org/10.1080/14649373.2016.1217630 }}$

Accepted version made available via SOAS Research Online: http://eprints.soas.ac.uk/23080/

Publishers and Raduga: their readership included many thousands of others, both adults and children.

Despite the censorious attitude taken by Panchayat period governments towards domestic written production, Nepalis were relatively free to acquire and read Soviet and Chinese literature. The censorship of the Panchayat period was selective and its severity varied over time; the regime itself also fostered its own style of developmental and quasi-revolutionary rhetoric. During the 1960s, according to one veteran leftist writer, “you could publish anything so long as it didn’t directly criticise the king or the Panchayat. Mao's writings were all available, as was the Peking Review and everything." 23 Moreover, Nepali authors and editors who wished to publish critical texts knew how to avoid the censor:

People were called in to explain the meaning of the works they published and black ink was poured over offending passages. But clever editors knew the chor bato. ${ }^{24}$ They would bribe presses to print their books and journals, then bring out complete copies without the name of the paper (patrika) or the publisher, and distribute them to leftist youths under cover of darkness. (Sangraula 2011, 277)

The Panchayat governments did not suppress the Russian and Chinese writings in the same way that they suppressed the works of local communist authors. The Russian and Chinese novels opposed capitalism, and by association also the western model of multi-party democracy: in this respect there was some common ground between Russian and Chinese state communism and the Panchayat ideology of partyless democracy. The Nepali government might also have been wary of offending the Chinese government by restricting access to the literature it distributed in Nepal, though it was less concerned about the Soviets, who were a more remote influence. ${ }^{25}$

This relative freedom was restricted to the Kathmandu urban area, however. Any Nepali caught carrying communist literature in rural districts was liable to have it confiscated and faced the likelihood of punishment, though often the severity with which this policy was enforced depended upon the whims of the local Zonal Commissioner (anchaladhish). A well known political columnist remembers that when he asked the Soviet Cultural Centre in Kathmandu for some books for a 
This is the version of the article accepted for publication in Inter-Asia Cultural Studies17 (3), 357-374 published by Taylor \& Francis available at: $\underline{\text { http://dx.doi.org/10.1080/14649373.2016.1217630 }}$

Accepted version made available via SOAS Research Online: http://eprints.soas.ac.uk/23080/

children's library in the Tarai district of Mohottari he was immediately sent a large bundle of publications and a bust of Lenin, which was promptly confiscated by the local police. ${ }^{26}$ Similarly, a leading social scientist recalls that when he lived in eastern Nepal, a friend who was bringing him some Russian books from Kathmandu was arrested and detained for seven days, even though the same books were freely available in the capital. ${ }^{27}$ In one of the early scenes of the Nepali film Balidan (1996), set in the dying days of the Panchayat regime, a young village woman is taken away, raped and murdered by the local police after they find a book hidden in the eaves of her house. The book is never identified, but its cover is unmistakably red in colour. ${ }^{28}$

When the Rana regime was overthrown in 1951, Kathmandu was still a small city of tightly packed domestic dwellings punctuated by temple squares and dominated by the palaces of the aristocracy, both new and old. The urban fabric provided very few indoor venues for non-religious meetings and gatherings, not to mention libraries, and the need for such facilities was met for many years by institutions established by friendly foreign powers. The Soviet-Nepal Cultural Association (sanskritik sangha) had a small office and reading room at Jamal, and the Soviet-Nepal Friendship Association (maitri sangha) which operated from Basantapur, had a library, a reading room and a large conference hall where Soviet films were shown regularly. An adjoining house provided an office for Mitra Kunj, an organisation of Nepali alumni of Soviet universities. The Nepal-China Friendship Association was located next door to the Soviet-Nepal Cultural Association, and next door to it was the Indian library: "all three in a row on the same side of the street.,"29

By the time of the Moscow-Beijing split in 1962 and the schism between proMoscow and pro-Beijing Nepali communists that followed, several outlets for the dissemination of Marxist literature had been established in Kathmandu. Basanta Thapa remembers that the "International Book House" was already well established in Kathmandu when he first arrived in the capital in 1970. Thapa soon took up a job as a part-time salesman:

My job was to man the shop and also send subscription forms in four duplicate copies to Mezdonarodnaya Kniga (MK) in Moscow. We used to sell subscription of magazines like Soviet Land, International Affairs, Sputnik Digest, New Times Weekly, Soviet Women, Soviet Literature etc. They were all 
This is the version of the article accepted for publication in Inter-Asia Cultural Studies17 (3), 357-374 published by Taylor \& Francis available at: $\underline{\text { http://dx.doi.org/10.1080/14649373.2016.1217630 }}$

Accepted version made available via SOAS Research Online: http://eprints.soas.ac.uk/23080/

published in English and the subscribers would get their copies by mail. There was also a monthly magazine in Nepali called Soviet Bhumi that was published by the Information Department of the Soviet Embassy. The magazine was edited by Mr. Shiva Prasad Upadhyaya. However, the chief of the department was Mr. Arbinda Rimal. ${ }^{30}$

At this time the store was managed by a politburo member of the pro-Moscow Rayamajhi faction of the Nepal Communist Party and it received bundles of books from the International Book Company in Moscow (Mezhdunarodnaya Kniga, founded 1923) probably as support in kind for the local party, which kept the proceeds from their sales.

In addition to the International Book House there were at least two other "progressive bookshops" in Kathmandu, of which Niranjan Baidya's Pragati Prakashan in Bhotahiti is the best remembered. While the International Book House was clearly aligned with Moscow, this was overtly pro-Beijing. Nepali communist intellectuals from one camp could not be seen in the bookshop of the other. For the Nepali Maoists,

Mao was like a god. Khrushchev was like a demon (danav). Everything published from China was like a bible, a Quran. Everything published from Russia was bad. ${ }^{31}$

Of course, the Nepali communists were also totally opposed to the literature that bore the stamp of their main political rivals, the Nepali Congress party. Outside Kathmandu there were communist book shops in several other towns, including Bhaktapur in the Kathmandu Valley and Biratnagar in the southern plains.

A Nepali translator's choice of a work for translation was often spontaneous and personal. A handful of Nepali translators translated Soviet novels from the original Russian, but translations of Chinese works were, without exception, based on preexisting English translations. Khagendra Sangraula is the best known Nepali translator of Chinese literature but the first book he translated was the Vietnamese novel The Village that Wouldn't Die: a story of Viet Nam's resistance war by Nguyen Ngoc (b. 1932), to which he gave the Nepali title Ajammari Gaun. This appeared in 
This is the version of the article accepted for publication in Inter-Asia Cultural Studies17 (3), 357-374 published by Taylor \& Francis available at: $\underline{\text { http://dx.doi.org/10.1080/14649373.2016.1217630 }}$

Accepted version made available via SOAS Research Online: http://eprints.soas.ac.uk/23080/

1971/2 (BS 2028), with friends covering the cost of printing and publication.

Sangraula told me that he translated this book because he wanted to help "prepare the environment for a revolution" in Nepal; subsequently he toured the villages of Lamjung, Tanahun and Chitwan districts with 100 copies of Mao's Little Red Book. After graduating from Tribhuvan University, Sangraula worked as a schoolteacher in the district of Chitwan, but the posting to that district of a notoriously hardline district administrator prompted him to relocate to Kathmandu. There he had no job, so he passed his days reading books from the shelves of Niranjan Baidya's shop in Bhotahiti. After a while Baidya proposed that Sangraula should translate the collected works of Mao for him. It emerged that another translator had already translated the first volume, but there were three more volumes awaiting translation:

The job seemed fine to me. I would get to translate the residue (nithar) of the experience of the Chinese revolution and the novel thoughts of Mao into Nepali, and also get a few pennies (anasuki) of wages: I was going to have laddus in both hands! (Sangraula 2011, 280-281)

Unfortunately, Niranjan Baidya is a notorious character in the history of the translation of Chinese literature into Nepali and numerous tales are told of his alleged dishonesty and exploitation of fellow party members. ${ }^{32}$ After a fee of Rs 6000 had been agreed upon for the translation of Volume 2, Sangraula discovered that the previous translator had been paid Rs 20,000 for translating Volume 1, which was only half as long as Volume 2. None the less, Sangraula translated not only the second volume but the third and fourth volumes too, and with no other means of supporting himself, he went on to translate other books for Baidya at the same measly rate. These included The Song of Youth (Yuvaharuko git), Lu Hsun's biography, and a collection of contemporary Chinese stories. ${ }^{33}$

\section{Proletarian novels and the Nepali Maoist reader}

Sangraula told me that Nepali Marxism was very simplistic and rigid in the beginning: 
This is the version of the article accepted for publication in Inter-Asia Cultural Studies17 (3), 357-374 published by Taylor \& Francis available at: $\underline{\text { http://dx.doi.org/10.1080/14649373.2016.1217630 }}$

Accepted version made available via SOAS Research Online: http://eprints.soas.ac.uk/23080/

Like a religious orthodoxy. Everything was black and white. It was very simple, there wasn't much for you to read.

The idea developed among activists on the extreme left that it wasn't good to read too widely, and that they should only read the necessary things:

Those directly involved in the political movement in Nepal, those who had not read much, who did not have wide horizons, read nothing except works translated from China. Gorki's Ama [Mother] and Ostrovsky's Agni Diksha [How The Steel was Tempered], because they were so famous, they were read too. But other Russian stuff, Chekhov, Tolstoy etc, I don't think they read those. $^{34}$

As I have already noted, five translated novels were almost universally cited by Maoist cadres in their answers to questions about the literature that had inspired them the most (Figure 2). There follow short summaries of each.

(Notes to typesetter: Please insert "HUTT_Figure02.JPG" here. Thank you.)

Figure 2. From left to right: Nepali translations of Ostrovsky's How the Steel was Tempered (Agni Diksha), Yang Mo's The Song of Youth (Yuvaharuko Git) and Gorki's Mother (Ama) in Pragati Pustak Bhandar in 2012.

Bright Red Star (Shanshande hongxing in the Chinese original, Chamkilo Rato Tara in its Nepali translation) is a revolutionary children's story by Li Xintian. This was first published in 1971 and was made into a feature film in 1974 (Bi 2013, 8385). It tells the story of Pan Dongxi, a boy whose father joins the underground Chinese communist party in 1931 and organises revolutionary activities against the tyrannical village landlord. The landlord fails to capture his father, but captures Pan Dongxi instead. He is about to be killed when the Red Army arrives and rescues him. A revolutionary government is set up in the village, and then the Red Army sets off on its Long March in 1934, with Pan Dongxi’s father among its number. Pan Dongxi's father gives him a red star badge to remember him by, and he is left behind with his mother. The evil landlord now returns to oppress the villagers once again, 
This is the version of the article accepted for publication in Inter-Asia Cultural Studies17 (3), 357-374 published by Taylor \& Francis available at: $\underline{\text { http://dx.doi.org/10.1080/14649373.2016.1217630 }}$

Accepted version made available via SOAS Research Online: http://eprints.soas.ac.uk/23080/

and Pan Dongxi and his mother flee to the mountains, from where they launch revolutionary activities against him. Pan Dongxi's mother is burned to death in a confrontation with the landlord's men, but Pan Dongxi himself escapes and grows up to become a staunch revolutionary fighter. The opportunity eventually arises for him to take his revenge on the evil landlord.

This is the work of Chinese fiction that is most commonly cited by younger cadres when they seek to explain why they were attracted to the Nepali Maoist movement. An English translation was published in 1974 and a Hindi translation in 1976, but these are now unobtainable, in Nepal at least. The first Nepali translation, by Pratik Dhakal, was published by Gunilo Prakashan in 1994/5 (Karmacharya and Ranjitkar 2002-3, 13), while a second Nepali rendition, by Sitaram Tamang, was published in 2000. Many of the 60-70 ex-PLA combatants who have published their memoirs in recent years used this book as a template for their accounts of their own early years.

Maxim Gorki's Mother (1907) is the story of a woman who is gradually drawn into revolutionary activism by her son. In their study of political activism in Nepal, Gellner and Karki state that her fervent belief in Christianity is "transformed into a faith in the necessity of fundamental, possibly violent, change and self-sacrifice to bring about a viable life for the mass of the people" and describe the characters of the novel as "simply drawn," with the revolutionaries all good and selfless and their enemies beastly, selfish and often sadistic (Gellner and Karki 2007, 386). While the entire novel is suffused and dominated by the "powerful symbol of a mother's love," the key passage is the three-page speech given by her son in defence of revolutionary socialism as he stands trial towards the end of the novel.

Gorki's Mother probably first appeared in Nepali translation in 1976 but was widely read in English and Hindi translations by Nepali political activists for many years before this. ${ }^{35}$ Describing it as the first kalatmak ghoshanapatra (artistic manifesto) of Marxist literature, Sangraula recalled it being discussed by fellow students in Kathmandu in the mid-1960s, and attributed its popularity to the fact that

it showed that the workers (shramik) can become organised, can launch a movement, can take the state and run it. And the view that the people's lives should be reflected in literature, this was a new opinion too. ${ }^{36}$ 
This is the version of the article accepted for publication in Inter-Asia Cultural Studies17 (3), 357-374 published by Taylor \& Francis available at: $\underline{\text { http://dx.doi.org/10.1080/14649373.2016.1217630 }}$

Accepted version made available via SOAS Research Online: http://eprints.soas.ac.uk/23080/

I think it is safe to say that Mother is the one non-Nepali book that practically every Nepali political activist has read. Gellner and Karki express surprise at the impact of this novel upon Nepali activists at the beginning of their discussion, but provide an explanation for it towards the end, saying that it is the universal symbol of the mother along with the "vivid if idealized" picture of underground revolutionary activism "that made the novel speak so powerfully to those growing up and being educated under the Panchayat regime" (Gellner and Karki 2007, 387). I think this is a part of the explanation, but I think Gellner and Karki also rather fail to empathise with what works as literature among a relatively unsophisticated readership.

Gorki's Mother was the second book Informant A ever read. She grew up in Mumbai and read it in Hindi. "I found Aama much easier to understand than the others. My parents were labourers (majdur) and we lived in a labourers' quarter. In Aama everyone was a labourer, so it seemed like my own, like I knew them, like my own matters (kura)." Later, when she read Chinese novels, she didn't understand everything because they detailed the lives of agriculturalists and peasants: "There was no connection, you know?... I liked The Song of Youth, but the Russian novels seemed closer to my own experience." 37

Another female ex-combatant was greatly inspired by the example of the mother in Gorki's novel. She told me:

We were in a movement, right? The mother's role, her contribution, her not becoming an informer (gaddar) despite all the suffering and crisis she underwent, it inspired us not to deviate from our line of thought. ${ }^{38}$

For her, the main impact of the novel came from the roles played by the characters in it, despite the fact that the social context was very different from Nepal's. This informant found the peasant novels from China easier to relate to, however.

Yang Mo's novel The Song of Youth was first published in China in 1958 and was made into a popular film in 1959. By March 1960 it had sold 1.7 million copies. The novel tells the story of Lin Daojing, who grows from a "melancholy, dreamy youth" into an ardent revolutionary as a result of the Japanese invasion of the early 1930s (Knight 2006, 141). Daojing is the daughter of an evil landlord's concubine, 
This is the version of the article accepted for publication in Inter-Asia Cultural Studies17 (3), 357-374 published by Taylor \& Francis available at: http://dx.doi.org/10.1080/14649373.2016.1217630

Accepted version made available via SOAS Research Online: http://eprints.soas.ac.uk/23080/

who commits suicide after she is expelled from his home and denied access to her baby. Sabina Knight writes that Daojing's subsequent attraction to the Party stems partly from her "intense yearning for community" (145) and that her political conversion comes "as a rational response to social injustice and national crisis, from less conscious emotional and psychological needs, and from a millenarian belief in history based on understandings of Marxist theory" (141). Although the novel was received positively at first, later reviewers disapproved of its focus on intellectuals and suggested that the heroine's political transformation was not developed sufficiently. So Yang Mo revised it, adding ten new chapters; seven of these describe the heroine's work in the countryside "and thus substantially increase her contact with peasants and sharpen the portrayal of her developing class consciousness" (141). The first Nepali translation, by Khagendra Sangraula, appeared in 1984/5 entitled Yuvaharuko Git (literally, "The Song of Youths"); this is now in its fourth edition.

Anil Barve's Thank You Mr Glad was first published in Marathi in 1975, and the first Nepali translation, translated by Prajval Shrestha, appeared in 1998/9 entitled Dhanyavad Glad Mahoday. There are also translations available in other South Asian languages, including Gujarati and Hindi, though apparently none in English. The novel is set in the original Naxalite movement era. A doctor-turned-Naxalite, Virbhushan Patnaik, is sentenced to death for killing several policemen. He is to be lodged in Rajahmundry Central Jail for a year before he is hanged. The jail superintendent is an Anglo-Indian named Mr. Glad, who lost his Jewish wife Miriam to the Nazi gas chambers and has lived in India since the end of the second World War. Mr. Glad is alcoholic and cruel but Virbhushan Patnaik disarms him with his polite but firm retorts, and Mr. Glad is gradually transformed: he ceases his torture of his prisoners and tries to secure a pardon for Dr Patnaik. Eventually, one stormy night, he is forced to ask Dr. Patnaik to perform an emergency Caesarean section on his daughter. The next day, as Dr Patnaik is about to enter the jeep which will take him to his death by hanging, Mr. Glad calls out "Comrade!" and shoots him in the chest. Thus, the Naxalite dies a hero's death and Mr. Glad becomes a prisoner in his own jail. There are strong parallels between the ending of this novel and the final scene of the Nepali film Balidan, referred to earlier.

One female informant who was imprisoned for many months told me, 
This is the version of the article accepted for publication in Inter-Asia Cultural Studies17 (3), 357-374 published by Taylor \& Francis available at: $\underline{\text { http://dx.doi.org/10.1080/14649373.2016.1217630 }}$

Accepted version made available via SOAS Research Online: http://eprints.soas.ac.uk/23080/

Thank You Mr Glad was in the jail library. ${ }^{39}$ I read it many times. When I read it I was very enthused (utsahit), when the police side was giving us grief ( $d u k h a)$, and I thought it would be good if we died like in Thank You Mr Glad. When they were giving us torture and I was feeling downcast (dikka). That character inspired us while we were in jail. ${ }^{40}$

As Ina Zharkevich $(2013,116)$ observes,

Books were crucial in reproducing the Maoist Movement and in ensuring the creation of an imaginary network of committed individuals: the mere act of reading certain books could make a person take part in the underground reality.

Although written in the third person, How the Steel was Tempered by Nikolai Ostrovsky (1904-36) is really a fictionalised autobiography. Described in the official Soviet history of Russian literature, Timofeyev's Russkaya Sovetskaya Literature (Moscow 1950), as "one of the leading works of Soviet literature" (Rühle 1969, 84), it sold 5 million copies in the Soviet Union between 1934 and the mid 1940s and became not only a feature film but also a Soviet TV series.

The novel's central character, Pavel Korchagin, is born to a poor village family. The novel begins with an account of his childhood, describing how his mind and character are moulded by the hostile environment that surrounds him. After a patchy education, he runs errands for the local Bolsheviks and later volunteers for the Red Army, from which, like Ostrovsky himself, he is demobilized on medical grounds after being seriously wounded in battle against the Germans; he returns from the battlefront determined to contribute to the forging of a new socialist society. Working in railway workshops, he serves the local Komsomol and becomes an implacable fighter against class enemies and a fiery organizer of collectivisation in the countryside. His dedication to the cause of the Revolution at first leads him to deny himself any kind of personal life, but later in life his mother and his wife, both of whom he has converted to the communist cause, become his closest comrades in arms. The building of a railway branch line becomes a metaphor for the construction of a new country, and it is during this backbreaking labour that the words are uttered: "thus is the steel tempered." 
This is the version of the article accepted for publication in Inter-Asia Cultural Studies17 (3), 357-374 published by Taylor \& Francis available at: $\underline{\text { http://dx.doi.org/10.1080/14649373.2016.1217630 }}$

Accepted version made available via SOAS Research Online: http://eprints.soas.ac.uk/23080/

The publishers of a 2002 edition of the English translation of this novel declare in their introduction,

In his portrayal of a young worker in the early years of the Revolution, Nikolai Ostrovsky revealed the typical features of not only the first Komsomol generation, but of the young man of the Lenin and Stalin epoch. This constitutes the chief contribution of Ostrovsky, the artist, and a victory for the method of socialist realism. And it is this that makes Pavel Korchagin immortal. (Ostrovsky 2002, 17)

Others disagree. Jürgen Rühle $(1969,85)$ writes,

In reading the book today one is appalled by its intransigence and lack of candor. Korchagin's conflicts have been smoothed over; the history of the Party has been tailored to order. There is something soulless and inhuman about the book.

Rühle goes on to say that Ostrovsky wanted only for his readers to be overcome by "the most beautiful of all feelings - that of devotion to our great Party." Ostrovsky, who had completely lost his sight by 1930 , began to compose and dictate his autobiographical novel in 1930-31. It was serialised in the Moscow journal Molodaya gvardiya [The Young Guard] before appearing as a book in 1934. The Nepali translation was produced by Rajendra Maske and published by Raduga Publisher in 1980. The translation of its title is ingenious: agni is the Sanskrit term for fire, which is personified in the Veda as a deity, while diksha means consecration or initiation. Thus the translator took the original concept of steel being tempered in fire (a metaphor that speaks most clearly to people familiar with an industrial context), and replaced it with a metaphor for ritual initiation that has heavy religious overtones. One former Maoist combatant told me that her commander once asked her what she had read, and then declared, "You cannot be a true Maoist if you haven't read Agnidiksha."41 
This is the version of the article accepted for publication in Inter-Asia Cultural Studies17 (3), 357-374 published by Taylor \& Francis available at: $\underline{\text { http://dx.doi.org/10.1080/14649373.2016.1217630 }}$

Accepted version made available via SOAS Research Online: http://eprints.soas.ac.uk/23080/

I do not wish to suggest that these translated novels are the only books that Maoist cadres read, because many had also read novels and other works by Nepali authors. Women cadres had invariably read Shirishko Phul (The Jacaranda Flower), a 1964 novel by Parijat, and many had also read more recent novels such as Yug Pathak's novel Urgenko Ghoda (Urgen's Horse; see Hutt 2014). In some cases I was surprised by the breadth of their reading. One told me of his love for the popular narrative poem Muna-Madan, first published in the 1930s, an edition of which he borrowed from a friend and copied out by hand overnight, and expressed his admiration for BP Koirala, who was one of the founding fathers of the Nepali Congress Party and a noted novelist. ${ }^{42}$ Tara Rai, a young Maoist activist whose memoir was acclaimed by Kathmandu civil society but decried by Nepali Maoist critics when it was published in 2010 (see Hutt 2013), includes both original Nepali titles and works translated from Chinese in a list of the books that inspired her political leanings (Rai 2010, 109).

\section{Conclusion}

It is interesting that the translated novel is the genre that appears to have had the greatest impact in this context. As Denning says, "radical writers have usually chosen shorter forms" (Denning 2007, 705), and in Nepali the clearest articulations of overtly political resistance are generally to be found in poetry and song. Until very recently even the indigenous Nepali novel more closely resembled a novella or an extended short story: works such as Kshetri's Basai (1954) and Parijat's Shirishko Phul (1964), widely regarded as landmarks in the history of the genre in Nepali, do not extend much beyond 100 pages. So Denning might be right that there is an inverse relation between the impact of the proletarian novel on a culture and the earlier importance of the novel in that culture. The Nepali readership was simply unused to reading fulllength novels, and many of the translated "landmark proletarian novels" are very long indeed: the Nepali edition of The Song of Youth, for instance, extends to 605 pages.

Due largely to the influence of great Indian writers such as Premchand and Rabindranath Tagore, an empirical strain of socialist realism was the defining characteristic of most mainstream Nepali novels of the period 1950-80, but these novels did not go much beyond describing social problems in heartrending detail. For 
This is the version of the article accepted for publication in Inter-Asia Cultural Studies17 (3), 357-374 published by Taylor \& Francis available at: http://dx.doi.org/10.1080/14649373.2016.1217630

Accepted version made available via SOAS Research Online: http://eprints.soas.ac.uk/23080/

instance, Basain is the story of a peasant family dispossessed of their land and home by unscrupulous moneylenders, and Shirishko Phul is a psychological study of an exGurkha who is tortured by his memories of rape and brutality. But neither novel proposes a political solution for the problem it identifies.

In contrast, it is significant that the large number of memoirs published by erstwhile Maoist combatants after the end of the internal conflict are very clearly modelled on the classic model of revolutionary bildungsroman that is found in Mother, The Song of Youth, Bright Red Star, How the Steel was Tempered and so on, in which the oppressed masses rise up and overwhelm the oppressors. Informant A compared these latterday Nepali communist texts unfavourably with their Russian and Chinese models:

Many have written wonderfully, but many have not, because they did not get guidance on how to write. They've done theoretical explanations, but sometimes they don't add up. Like, if you read The Song of Youth, the whole feeling comes to you. Or when you're reading Mother - no, they weren't able to bring it out like that. Our mothers were much more actively involved in the People's War than Gorki's mother was. The mother who put a tika on her son's forehead and sent him to the People's War is much more revolutionary than Maxim Gorki's mother. But no one has written that. ${ }^{43}$

Thus, works originally written in Russian and Chinese, but now almost entirely unread in their cultures of origin, were given a new lease of life by a non-metropolitan Nepali readership in a very particular context. Did they become "world literature" texts in the process? David Damrosch $(2003,4)$ might argue so, for he suggests that "world literature" encompasses "all literary works that circulate beyond their culture of origin" and that "a work only has an effective life as world literature whenever, and wherever, it is actively present within a literary system beyond that of its original culture." In fact, in Damrosch's $(2003,5)$ view world literature is not a canon of works but rather "a mode of circulation and of reading." Further, a work may function as world literature "for some readers but not others, and for some kinds of reading but not others." 
This is the version of the article accepted for publication in Inter-Asia Cultural Studies17 (3), 357-374 published by Taylor \& Francis available at: $\underline{\text { http://dx.doi.org/10.1080/14649373.2016.1217630 }}$

Accepted version made available via SOAS Research Online: http://eprints.soas.ac.uk/23080/

In his discussion of "literary interference," Itamar Even-Zohar $(1990,62)$ points out that the phenomenon he describes contains no symmetry: "A target literature is, more often than not, interfered with by a source literature which completely ignores it.” Indeed, if a "world literary system” can be said to exist, as Moretti $(2000,56)$ admits, it can only be profoundly unequal. As Francesca Orsini has recently argued, the influential conceptualisations of "world literature" offered by scholars such as Moretti, Casanova (2004) and others imply the existence of a hierarchy that makes the vast majority of literature produced in the world "hopelessly peripheral.",44

In Damrosch's terms, literature that circulates (usually in translation) is "world literature," while literature that is neither translated nor circulated is purely local or regional. However, the "technologies of recognition," as Shu-Mei Shih $(2004,17)$ points out, are based upon "mechanisms in the discursive (un)conscious... that produce "the West" as the agent of recognition and "the rest" as the object of recognition" - and, as we have seen, the Nepali literary world remains largely invisible to the "international literary authorities" (Casanova 2004,183). So if these old socialist texts have been revitalised in a Nepali context, it is a process that remains unnoticed by the wider world, which thinks of these books as things of the past, if it thinks of them at all. Despite the political and literary impact of these circulations at local level, as long as standard conceptualisations of "world literature" remain predicated upon a process in which "regional literatures" become subordinated to a European literary hegemony, they will not be able to take sufficient account of literary exchanges and circulations in areas they deem peripheral.

\section{Notes}

\footnotetext{
${ }^{1}$ Nepali literary historiography has generally been "tendentiously nationalistic"
} (Even-Zohar 1990, 57), making only scant reference to outside influences. This is probably because its standard works of reference were written during the Panchayat period of Nepal's political history (1962-90), during which there was a compulsion to present the development of literature in the Nepali language as something driven by an internal dynamic, and to invest it with a standing equal to that of literature in the major world languages, not merely a minor branch of a South Asian literary tree (see, for instance, Sharma [1982]; Shrestha and Sharma 
This is the version of the article accepted for publication in Inter-Asia Cultural Studies17 (3), 357-374 published by Taylor \& Francis available at: $\underline{\text { http://dx.doi.org/10.1080/14649373.2016.1217630 }}$

Accepted version made available via SOAS Research Online: http://eprints.soas.ac.uk/23080/

[1977]). However, despite the efforts of Nepali literary historians, I am not aware of any study of "world literature" that mentions Nepali literature at all.

${ }^{2}$ A Nepali version of Maoism emerged during the 1960s, and its adherents waged war against the Nepali state from 1996 to 2006. After the loss of some 16,000 lives, the conflict ended in a political settlement which included the abolition of the Shah monarchy that first "unified" Nepal in 1769 and the election of a Constituent Assembly.

${ }^{3}$ Recorded interviews with Ganga Bahadur Lama, Khopan (Kathmandu), 11 July 2012 and 19 July 2013. A total of nine interviews with former Maoist combatants, each of between one and two hours in duration, were conducted in Kathmandu for the purposes of this article. All interviews were conducted in Nepali, and all translations from Nepali in this article are my own. Six former combatants are quoted directly in this article and five are referred to as "Informant A," "Informant B" etc to protect their identities. As a published author my principal informant, Ganga Bahadur Lama, is readily identifiable, and his name is used here with his permission.

${ }^{4}$ Recorded interview with Informant A, Kathmandu, 22 July 2012. The "schooling" was delivered in the safest place in a district, usually to 10-15 people at a time. Its venue would change at regular intervals to avoid detection by the security forces. There were different levels of instruction, according to rank. There was no assessment, but in at least one location the best students would turn their lessons into song performances: "cultural programmes" of this nature were staged regularly by Maoist troupes to mobilize support in Nepali villages.

${ }^{5}$ Malema ra Prachandapathiya Skuling Pathyakram, madhyamik ra uccastarko lagi ("The Marxism-Leninism-Maoism and Prachand Path Schooling Syllabus, for middle and upper grades”). Dated 2007, this was a second edition of the syllabus, of which a first edition was printed in 2004, ie., two years before the end of the conflict. The syllabus was presumably a list of materials used in the "schooling programme" for some years prior to 2004 .

${ }^{6}$ Personal communication, Informant B, Bag Bazaar (Kathmandu), 13 July 2012.

${ }^{7}$ Recorded interview with Ganga Bahadur Lama, Khopan (Kathmandu),11 July 2012.

${ }^{8}$ Recorded interview with Informant C, Thapathali (Kathmandu), 22 July 2012.

${ }^{9}$ Recorded interview with Informant C, Thapathali (Kathmandu), 25 July 2012. 
This is the version of the article accepted for publication in Inter-Asia Cultural Studies17 (3), 357-374 published by Taylor \& Francis available at: $\underline{\text { http://dx.doi.org/10.1080/14649373.2016.1217630 }}$

${ }^{10}$ Recorded interview with Informant D, Bag Bazaar (Kathmandu), 4 April 2012.

${ }^{11}$ Recorded interview with Hemanta Oli, UNCP (M) headquarters, Paris Danda (Kathmandu), 23 July 2012.

${ }^{12}$ Recorded interview with Informant A, Thapathali (Kathmandu), 22 July 2012. The book she refers to is probably Kiran ([2003-4] 2006-7).

${ }^{13}$ Recorded interview with Informant C, Thapathali (Kathmandu), 25 July 2012.

${ }^{14}$ Ibid.

${ }^{15}$ Recorded interview with Informant E, Thapathali (Kathmandu), 25 July 2012.

${ }^{16}$ Conversation with Kailash Rai (researcher, Martin Chautari), Informants C, E and others, Thapathali (Kathmandu), 25 July 2012.

${ }^{17}$ Khagendra Sangraula, recorded interview, Kathmandu 16 July 2012.

${ }^{18}$ Personal communication, Govinda Raj Bhattarai, Kirtipur 10 July 2014.

${ }^{19}$ Basanta Thapa recalls that Mao's "Little Red Book" was freely available in Nepal by the mid-1960s (personal communication via email, 6 August 2014), and his colleague Sudarshan Karki remembers that when he lived in Banepa during the 1970s anyone who purchased a book from the local bookstore was handed a copy of it for free (personal communication 21 July 2014).

${ }^{20}$ Arbinda Rimal, personal communication, Kathmandu, 20 July 2014. Krishna Prakash Shrestha notes a reference by the Russian writer Sergei Baruzdin to a 1963 conversation with the then minister of transport and communications, Kedar Man Vyathit, in which Vyathit promised to promote a programme of mutual translation (Shrestha 2000, 131), but this does not appear to have been implemented.

${ }^{21}$ My thanks to Arbinda Rimal for lending me his precious sole personal copy of his memoir.

${ }^{22}$ Nilambar Acharya, personal communication, Kathmandu, 22 July 2014.

${ }^{23}$ Khagendra Sangraula, recorded interview, Kathmandu, 16 July 2012.

${ }^{24}$ The chor bato is literally "the thief's road," ie. an escape route or a path along which people can travel undetected.

${ }^{25}$ Nilambar Acharya, personal communication, Kathmandu, 22 July 2014.

${ }^{26}$ CK Lal, personal communication, Kathmandu, 11 July 2014.

${ }^{27}$ Deepak Thapa, personal communication, Kathmandu, 13 July 2014.

${ }^{28}$ Balidan, directed by Tulsi Ghimire, is a film about a group of anti-Panchayat activists on the run in rural Nepal. Released in 1996, it was briefly banned in 2005 
This is the version of the article accepted for publication in Inter-Asia Cultural Studies17 (3), 357-374 published by Taylor \& Francis available at: $\underline{\text { http://dx.doi.org/10.1080/14649373.2016.1217630 }}$

Accepted version made available via SOAS Research Online: http://eprints.soas.ac.uk/23080/

during then King Gyanendra's attempt to regain executive power. The entire film may be viewed at youtube.com/watch? $\mathrm{v}=1-\mathrm{xyNVRwZZY}$.

${ }^{29}$ Basanta Thapa, personal communication via email, 6 August 2014.

${ }^{30}$ Ibid.

${ }^{31}$ Khagendra Sangraula, recorded interview, Kathmandu 16 July 2012.

${ }^{32}$ See, for instance, the memoirs of the veteran communist leader Shambhuram Shrestha (Shrestha 2007).

${ }^{33}$ This brief account of Khagendra Sangraula's career as a translator is based on Sangraula (2011) and my recorded interview with him on 16 July 2012.

${ }^{34}$ Khagendra Sangraula, recorded interview, Kathmandu 16 July 2012.

${ }^{35}$ At least three Nepali translations of Gorki's Mother have been published. The first, by Badri Narayan Pradhan (Shyam Brothers, Darjeeling 1976) was based on an English translation; the second, by Rajendra Maske (Raduga Publisher, Moscow, 1995) on the Russian original, and the third, by Baburam Bhattarai (Asia Publications, Butwal, 1998-9) on a Hindi translation (Karmacharya and Ranjitkar 2002-3, 12).

${ }^{36}$ Khagendra Sangraula, recorded interview, Kathmandu 16 July 2012.

${ }^{37}$ Recorded interview with Informant A, Thapathali (Kathmandu), 22 July 2012,

${ }^{38}$ Recorded interview with Informant C, Thapathali (Kathmandu), 25 July 2012.

${ }^{39}$ The term "library" is probably being used very loosely here. It seems unlikely that a Nepali jail would possess anything more than a modest collection of books.

${ }^{40}$ Recorded interview with Informant C, Thapathali (Kathmandu), 25 July 2012.

${ }^{41}$ Recorded interview with Informant C, Thapathali (Kathmandu), 25 July 2012.

${ }^{42}$ Recorded interview with Informant D, Bag Bazaar (Kathmandu), 4 April 2012.

${ }^{43}$ Recorded interview with Informant A, Thapathali (Kathmandu), 22 July 2012.

${ }^{44}$ Francesca Orsini, "Significant geographies in lieu of "world literature'." Presentation to the Centre of Cultural, Literary and Postcolonial Studies, SOAS University of London, 21 January 2015.

\section{Acknowledgement}

The initial research for this article was supported by British Academy South Asia International Partnership award no. IP090191, "The construction of public meaning during Nepal's democratic transition" [between SOAS (London) and Martin Chautari 
This is the version of the article accepted for publication in Inter-Asia Cultural Studies17 (3), 357-374 published by Taylor \& Francis available at: $\underline{\text { http://dx.doi.org/10.1080/14649373.2016.1217630 }}$

Accepted version made available via SOAS Research Online: http://eprints.soas.ac.uk/23080/

(Kathmandu)]. I would like to thank all of the informants who generously spared the time to talk to me in Kathmandu, and especially Kailash Rai for arranging several key interviews.

\section{Notes on contributor}

Michael Hutt is Professor of Nepali and Himalayan Studies at SOAS (the School of Oriental and African Studies), University of London. He has published extensively on Nepali literature, of which he is also a noted translator, and on Nepali politics. His recent publications include Poetry and Politics in Post-Rana Nepal: the life of Bhupi Sherchan (New Delhi, Oxford University Press, 2010); Eloquent Hills: Essays on Nepali Literature (Kathmandu: Martin Chautari, 2012); and "The Last Himalayan Monarchies" in Facing Globalization in the Himalayas: Belonging and the Politics of the Self (edited by Gérard Toffin and Joanna Pfaff-Czarnecka; New Delhi: Sage Publications, 2014).

Contact address: South Asia Institute, SOAS University of London. Russell Square, London WC1H 0XG. UK Email: m.hutt@ soas.ac.uk

\section{References}

Adhikari, Aditya. 2014. The Bullet and the Ballot Box. New Delhi: Aleph Book Company.

Anjaneyulu, D. 1978. “The Impact on Telugu Literature.” In October Revolution. Impact on Indian Literature, edited by Qamar Rais. New Delhi: Sterling Publishers.

Bi, Lijun. 2013. “Chinese Children's Literature in the Cultural Revolution (19661976)." Studies in Literature and Language 6 (1): 82-86.

Casanova, Pascale. 2004. The World Republic of Letters. Cambridge Massachusetts: Harvard University Press.

Chattopadhyay, Gautam. 1978. “Impact on Bengali Literature.” In October

Revolution. Impact on Indian Literature, edited by Qamar Rais. New Delhi:

Sterling Publishers.

Chauhan, Jangab. 2005. “Devkota in Russia.”Bodhi 3 (1): 99-105. 
This is the version of the article accepted for publication in Inter-Asia Cultural Studies17 (3), 357-374 published by Taylor \& Francis available at: $\underline{\text { http://dx.doi.org/10.1080/14649373.2016.1217630 }}$

Accepted version made available via SOAS Research Online: http://eprints.soas.ac.uk/23080/

Choudhary, Surendra. 1978. "Decades of Ideological Cold War and Hindi Literature." In October Revolution. Impact on Indian Literature, edited by Qamar Rais. New Delhi: Sterling Publishers.

Damrosch, David. 2003. What is World Literature? Princeton and Oxford: Princeton University Press.

Denning, Michael. 2007. “The Novelists' International.” In The Novel, edited by Franco Moretti. Princeton: Princeton University Press.

Even-Zohar, Itimar. 1990. "Laws of Literary Interference.” Poetics Today 11 (1): 5372.

Gellner, David N., and Mrigendra Bahadur Karki. 2007. "The Sociology of Activism in Nepal: Some Preliminary Considerations.” In Northern South Asia: Political and Social Transformations, edited by H. Ishii, D.N. Gellner and K. Nawa. New Delhi: Manohar.

Hutt, Michael. 2013. "Reading Nepali Maoist Memoirs."Studies in Nepali History and Society 17 (1): 107-142.

Hutt, Michael. 2014. "Writers, Readers and the Sharing of Consciousness: Five Nepali Novels."Himalaya 34 (2): 18-30.

Janamukti Sena Nepal. [2003-4] 2007-8. Malema ra Prachandapathiya Skuling Pathyakram, Madhyamik ra Uccastarko lagi [Marxism-Leninism-Maoism and Prachand-Path schooling curriculum, for intermediate and high grades]. Janamukti Sena Nepal, Paschim Sainya Kamand.

Karmacharya, Madhavlal, and Ishwarman Ranjitkar, eds. 2002-3. Anuvad Granth-

Suchi [Translation bibliography]. Kathmandu: Nepal Rajakiya Prajna-

Pratishthan.

KC, Surendra. 1999. Nepalma Kamyunist Andolanko Itihas [The history of the communist movement in Nepal]. Kathmandu: Bidyarthi Pustak Bhandar.

Kiran [2003-4] 2006-7. Sangharshako Darshan [The philosophy of struggle]. Nepal: Jandisha Prakashan.

Knight, Sabina. 2006. The Heart of Time: Moral agency in twentieth-century Chinese fiction. Cambridge: Harvard University Asia Center.

Kumar, Dhruba. 1980. “An Interlude in Nepal-China Relations during the Cultural Revolution."The Nepalese Journal of Political Science 2 (2): 19-40. 
This is the version of the article accepted for publication in Inter-Asia Cultural Studies17 (3), 357-374 published by Taylor \& Francis available at: $\underline{\text { http://dx.doi.org/10.1080/14649373.2016.1217630 }}$

Accepted version made available via SOAS Research Online: http://eprints.soas.ac.uk/23080/

Lama, Gangabahadur, Magh. 2008-9. Dasbarse Janayuddha Smritika Dobharu [Tenyear People's War: marks of memory]. Kathmandu: Jagaran Book House.

Mitra Kunj. 2000. Mitra Kunj Directory 2000. Kathmandu: Russian Centre of Science and Culture.

Moretti, Franco. 2000. “Conjectures on World Literature.”New Left Review Jan/Feb 2000: 54-68.

Ostrovsky, Nikolai. 2002. How the Steel was Tempered. Sydney: Communist Party of Australia.

Rai, Tara. 2010. Chapamar Yubatiko Dayari [The diary of a guerrilla girl]. Kathmandu: Ratna Pustak Bhandar.

Rimal, Arbinda. 2005. 1997 Saldekhi 2017 Sal: Ek Avalokan. [From 1997 to 2017: a view] Kathmandu: Tankaprasad Acharya Smriti Pratishthan.

Rühle, Jürgen. 1969 Literature and Revolution. A Critical Study of the Writer and Communism in the Twentieth Century. London: Pall Mall Press.

Sangraula, Khagendra. 2011. "Bam prakashan-sangathansanga mero sahavas.” [My co-residence with leftwing publishing organisations.] Midiya Adhyayan 6: 275291.

Sanyal, Ashish. 1978. “The Impact on Bengali Literature.” In October Revolution. Impact on Indian Literature, edited by Qamar Rais. New Delhi: Sterling Publishers.

Sharma, Taranath 1982. Nepali Sahityako Itihas [A history of Nepali literature]. Kathmandu: Sahayogi Prakashan.

Shih, Shu-Mei. 2004. "Global Literature and the Technologies of Recognition."PMLA 119 (1): $16-30$.

Shrestha, Dayaram, and Mohanraj Sharma. 1977. Nepali Sahityako Sankshipta Itihas [A concise history of Nepali literature]. Kathmandu: Royal Nepal Academy. Shrestha, Krishna Prakash. 2000 Rusma Nepalko Chavi [The reputation of Nepal in Russia]. Moscow: Himal Prakashan Guthi.

Shrestha, Shambhuram. 2007. Mero Rajnaitik Jivanka Samsmaranharu [Reminiscences from my political life]. Kathmandu: Gvahali Guthi.

Tripathi, Vishva Nath. 1978. "Impact on Hindi Literature.” In October Revolution. Impact on Indian Literature, edited by Qamar Rais. New Delhi: Sterling Publishers. 
This is the version of the article accepted for publication in Inter-Asia Cultural Studies17 (3), 357-374 published by Taylor \& Francis available at: http://dx.doi.org/10.1080/14649373.2016.1217630

Accepted version made available via SOAS Research Online: http://eprints.soas.ac.uk/23080/

Zharkevich, Ina. 2013. "Learning in a Guerrilla Community of Practice: Literacy

Practices, Situated Learning and Youth in Nepal's Maoist Movement."

European Bulletin of Himalayan Research 43: 104-132. 